\section{IJ§ER}

ISSN: 2149-5939
International Journal of Social Sciences and Education Research

Online, http://dergipark.gov.tr/ijsser

Volume: 2(3), 2016

\title{
Performance evaluation of electricity generation companies traded on BIST according to the financial parameters through the application of TOPSIS method
}

\author{
Muhammer İlkuçar ${ }^{1} \quad$ Ahmet Çifci $^{2}$
}

Received Date: 03 / 03 / 2016

Accepted Date: 01 / 04 / 2016

\begin{abstract}
Electrical energy is essential to the economic and social development and will improve the quality of life in any nation. Recently, a great deal of attention has been received and a fairly large body of literature has been focused on the TOPSIS method. In this study, the financial performance of 6 electricity generation companies whose shares are traded in the BIST are evaluated with multi decision making analysis by using financial ratios. The study conducted. NET framework coded in C\# programming language.
\end{abstract}

Keywords: Electricity company; Performance Criteria; TOPSIS; BIST; C\#.

\section{Introduction}

Energy is one of the most important components in developing countries. Energy plays a critical role in the economic growth, progress, and development, as well as poverty alleviation and security of any nation. Energy exists in many forms but the most important form is the electrical energy. Electrical energy can be easily converted into other forms of energy and transmitted from one place to another with the help of conductors. Electrical energy is essential to the economic and social development and will improve the quality of life in any nation.

The Turkish electricity sector is going through a rapid growth, mainly due to rising demand. Similar to the electricity sector, both consumption and generation of electricity is increasing as well. As reported by the Turkish Electricity Transmission Company (Turkiye Elektrik İletim A.S., TEIAS), the installed capacity in Turkey in 2014 was $69519,8 \mathrm{MW}$, while this figure rose by $5,2 \%$ in 2015 , reaching $73146,7 \mathrm{MW}$. Turkey's installed power capacity stands today at around $75 \mathrm{GW}$ and the aim is to have $100 \mathrm{GW}$ of installed capacity by 2023 . The total installed capacity is made up of The Electricity Generation Company (EUAS), independent power producers, the build-own-operate power plants, the build-own-operate-transfer power plants, the auto-producers and companies operating under transfer of operating rights agreements.

Power generation capacity has increased significantly. In 2015, total net electricity generation increased by $3 \%$ compared to 2014 . The Turkish electricity generation is largely dominated by natural gas/LNG powered electric plants (37,8\%), coal (lignite, imported coal and hard coal) powered plants $(30 \%)$ and hydroelectric plants $(25,8)$. Wind power plants constitute about $4,4 \%$ of total electricity generation in Turkey. Geothermal power plants accounted for $1,3 \%$ and biogas

\footnotetext{
${ }^{1}$ Asst. Prof. Dr., Mehmet Akif Ersoy University, BURDUR/TURKEY, imuammer@mehmeakif.edu.tr

${ }^{2}$ Corresponding author, Asst. Prof. Dr., Mehmet Akif Ersoy University, BURDUR/TURKEY, acifci@mehmetakif.edu.tr
} 
İlkuçar, M., Çifci, A. (2016). Performance evaluation of electricity generation companies traded on BIST according to the financial parameters through the application of TOPSIS method. International Journal of Social Sciences and Education Research, 2 (3), 815-824.

power plants $0,6 \%$. The nuclear energy is not used yet as power generation resource in Turkey. But, Turkey intends to have it first nuclear power plant operating until 2023. Distribution of The Turkish electricity generation according to the sources is given in Figure 3 (TEIAS, 2015).



Figure 1. Distribution of the Turkish electricity generation (TEIAS, 2015).

The Turkish Electricity Authority (TEK) was established by the Electricity Market Law number 1312 issued in 1970. TEK was split into two state owned enterprises in 1993: one for generation and transmission, the Turkish Electricity Generation and Transmission Company (TEAS) and the other for distribution, the Turkish Electricity Distribution Company (TEDAS). TEAS was restructured to form three state-owned public enterprise, namely the Electricity Generation Corporation (EUAS), the Turkish Electricity Transmission Corporation (TEIAS), and the Turkish Electricity Trading and Contracting Corporation (TETAS) in 2003 upon the taking effect of the Electricity Market Law number 4628 (TEIAS, 2016). Turkey's distribution network was divided into 21 distribution regions within privatization based on the Electricity Sector Reform and Privatization Strategy Paper (OIB, 2004). TEIAS signed a Long Term Agreement with the continental European members of ENTSO-E on the permanent synchronous operations of the Turkish power system with Continental Europe synchronous area on 15 April 2015.

Recently, a great deal of attention has been received and a fairly large body of literature has been focused on the Technique for Order Preference by Similarity to Ideal Solution (TOPSIS) method. Financial ratio analysis is one of the most widely used fundamental analysis techniques. Feng and Wang (2000) investigated a performance evaluation process for Taiwan's five major airlines with financial ratios. They used the grey relation analysis to select the representative indicators and used the TOPSIS method. Yurdakul and İç (2003) used the TOPSIS method for the financial performance evaluation of five large-scale public companies that operates in the Turkish automotive industry. Wang (2008) implemented fuzzy multi-criteria decision making approach to evaluate financial performance of domestic airlines in Taiwan. Ertuğrul and Karakaşoğlu (2009) used a fuzzy multi-criteria decision making model for performance evaluation of Turkish cement firms by using some of the traditional accounting-based financial ratios. Dumanoğlu ve Ergül (2010) analyzed financial performances of 11 technology firms whose shares are traded on the Istanbul Stock Exchange (ISE) with the TOPSIS method by using financial statements for the period 2006-2009. Bülbül and Köse (2011) evaluated the financial performance of 19 Turkish food companies whose shares are traded on the ISE with multi decision making analysis by using financial ratios. See also Meydan et al. (2016), where authors evaluated financial performance of food companies traded on the ISE using Grey Relational Analysis. Uygurtürk and Korkmaz 
İlkuçar, M., Çifci, A. (2016). Performance evaluation of electricity generation companies traded on BIST according to the financial parameters through the application of TOPSIS method. International Journal of Social Sciences and Education Research, 2 (3), 815-824.

(2012) analyzed financial performances of 13 basic metal industry enterprises whose shares are traded on the ISE with the TOPSIS method by using financial statements for the period 20062010. An application of evaluating the performance of 23 Greek manufacturing sectors with the use of financial data has been provided by Halkos and Tzeremes (2012). Mandic et al. (2014) proposed a fuzzy multi-criteria model that will facilitate the assessment of the financial performance of Serbian banks for the period between the years 2005 and 2010. In addition, financial performances of 7 tourism firms traded in the Borsa Istanbul (BIST) have been evaluated as to eight financial ratios including liquidity, leverage, profitability and activity indicators between the period 2010-2014 by Özçelik and Kandemir (2015). The main objective of this study is to evaluate the financial performance of 6 electricity generation companies whose shares are traded in the BIST with multi decision making analysis by using financial ratios. For this purpose, the TOPSIS method is used in this study.

The paper is organized as follows: The next section presents introduction of 6 electricity generation companies. The main idea of the TOPSIS method is outlined in section 3. Section 4 presents the financial performance of 6 electricity generation companies. Finally, the last section concludes the paper.

\section{The electricity generation companies}

In this paper, financial performances of 6 electricity generation companies whose shares are traded in the BIST are analyzed with the TOPSIS method by using financial ratios for 2015 . The information of financial ratios calculation used was derived from the annual financial statements published on BIST (2016), Public Disclosure Platform (KAP, 2016) and Bigpara (2016) websites. The electricity generation companies studied are shown in Table 1.

Table 1 . The electricity generation companies.

\begin{tabular}{|c|c|l|}
\cline { 2 - 3 } \multicolumn{1}{c|}{} & BIST Share Name & \multicolumn{1}{c|}{ Company Name } \\
\hline $\mathrm{A}_{1}$ & AKENR & Akenerji Electricity Generation Inc. \\
\hline $\mathrm{A}_{2}$ & AKSEN & Aksa Energy Generation Inc. \\
\hline $\mathrm{A}_{3}$ & AKSUE & Aksu Energy and Trade Inc. \\
\hline $\mathrm{A}_{4}$ & AYEN & Ayen Energy Inc. \\
\hline $\mathrm{A}_{5}$ & ODAS & Odas Electricity Generation Industry and Trade Inc. \\
\hline $\mathrm{A}_{6}$ & ZOREN & Zorlu Energy Electricity Generation Inc. \\
\hline
\end{tabular}

\section{TOPSIS}

The TOPSIS is a multi-criteria decision technique. This technique is developed by Hwang \& Yoon (1981). According to this method solution is calculated using Euclidian distance formula between positive and negative ideal solution of criteria. Performance of alternative is determined with nearest to positive ideal solution and farthest to negative ideal solution. The positive ideal solution has the maximum value of benefit criteria, minimum value of cost criteria (Equation 5). The negative ideal solution has the maximum value of cost criteria; minimum value of benefit criteria (Equation 6) Table 2 shows the structure of a type of multiple criteria decision problem. 
İlkuçar, M., Çifci, A. (2016). Performance evaluation of electricity generation companies traded on BIST according to the financial parameters through the application of TOPSIS method. International Journal of Social Sciences and Education Research, 2 (3), 815-824.

Table indicate that alternative which is denoted $i=1,2, \ldots, m$; criteria $j: 1,2, \ldots n ; x_{\mathrm{ij}}$ value demonstrate the criteria performances of alternative (Yu et all., 2011).

Table 2. A type of multiple-criteria decision problem.

\begin{tabular}{ccccc}
\hline & Criterion 1 & Criterion 2 & $\ldots$ & Criterion $\mathrm{n}$ \\
\hline Alternative 1 & $\mathrm{x}_{11}$ & $\mathrm{x}_{12}$ & $\ldots$ & $\mathrm{x}_{1 \mathrm{n}}$ \\
Alternative 2 & $\mathrm{x}_{21}$ & $\mathrm{x}_{12}$ & $\ldots$ & $\mathrm{x}_{2 \mathrm{n}}$ \\
$\ldots$ & $\ldots$ & $\ldots$ & $\mathrm{x}_{\mathrm{ij}}$ & $\ldots$ \\
Alternative $\mathrm{m}$ & $\mathrm{x}_{\mathrm{m} 1}$ & $\mathrm{x}_{12}$ & $\ldots$ & $\mathrm{x}_{\mathrm{mn}}$ \\
\hline
\end{tabular}

Figure 2. Flow chart of TOPSIS method.



Flow chart of TOPSIS method's calculation steps are shown in Figure 2. Alternative whose performances are to be compared are defined. The criteria of alternatives are defined. A matrix of alternative and criteria are formed and data is set (Equation1). Then matrix is normalized with each of values in column are divided to sum of respective matrix column (Equation2, 3). 
İlkuçar, M., Çifci, A. (2016). Performance evaluation of electricity generation companies traded on BIST according to the financial parameters through the application of TOPSIS method. International Journal of Social Sciences and Education Research, 2 (3), 815-824.

$$
\begin{aligned}
& \begin{array}{llll}
C_{1} & C_{2} & \cdots & C_{n}
\end{array} \\
& X_{i j}=\begin{array}{c}
A_{1} \\
\vdots \\
A_{m}
\end{array}\left[\begin{array}{cccc}
X_{11} & X_{12} & \cdots & X_{1 n} \\
\vdots & X_{i j} & \vdots \\
X_{m 1} & X_{m 2} & \cdots & X_{m n}
\end{array}\right] \quad(i=1,2, \ldots, m ; j=1,2, \ldots, n) \\
& Y_{i}=\sqrt{\sum_{i=1}^{m}\left(X_{i j}\right)^{2}} \\
& R_{i j}=\frac{X_{i j}}{Y i} \quad(i=1,2, \ldots, m ; j=1,2, \ldots, n)
\end{aligned}
$$

Weight values of criteria are assigned by an expert. Weight values must be between 0 and 1 $\left(0<w_{j}<1\right)$. Sum of criteria weight values must be 1 . Equation 4 is acquired by multiplying weight values and respective criteria of alternative $\left(V_{i j}=w_{i} * R_{i j}\right)$.

$V_{i j}=\left[\begin{array}{cccc}w_{1} R_{11} & w_{2} R_{12} & \ldots & w_{1} R_{1 n} \\ & \vdots & \ddots & \vdots \\ w_{1} R_{m 1} & w_{2} R_{n 2} & \cdots & w_{n} R_{m n}\end{array}\right] \quad(i=1,2, \ldots, m ; j=1,2, \ldots, n)$

The positive ideal value $\left(A_{i}^{+}\right)$is maximum value of benefit criteria, minimum value of cost criteria (Equation 5). The negative ideal solution is maximum value of cost criteria, minimum value of benefit criteria (Equation 6).

$$
\begin{aligned}
& A_{i}^{+}=\left\{\begin{array}{l}
\operatorname{Max}\left(V_{i j}\right), \text { Benefit }, j \in J, i=1,2, \ldots, m \\
\operatorname{Min}\left(V_{i j}\right), \text { Cost }, \quad j \in J, \quad i=1,2, \ldots, m
\end{array}\right. \\
& A_{i}^{-}=\left\{\begin{array}{l}
\operatorname{Min}\left(V_{i j}\right), \text { Benefit }, j \in J, i=1,2, \ldots, m \\
\operatorname{Max}\left(V_{i j}\right), \text { Cost }, \quad j \in J, i=1,2, \ldots, m
\end{array}\right.
\end{aligned}
$$

Distance of alternative from positive and negative ideal solution is calculated using Euclidean Distance Formula (Equation 7, 8). Performances of alternatives are determined according to relative proximity to positive and negative ideal solution (Equation 9 ). $D_{i}$ being greater indicates that the relevant alternative is closer to positive ideal solution (Aktaş et al., 2015). If $D_{i}=1$ then alternate is point of positive ideal solution and if $\mathrm{D}_{\mathrm{i}}=0$ then alternate is point of negative ideal solution (Özdağoğlu, 2013).

$$
\begin{aligned}
& D_{i}^{+}=\sqrt{\sum_{j=1}^{n}\left(V_{i j}-A_{j}^{+}\right)^{2}} \quad(i=1,2, \ldots, m ; j=1,2, \ldots, n) \\
& D_{i}^{-}=\sqrt{\sum_{j=1}^{n}\left(V_{i j}-A_{j}^{-}\right)^{2}} \quad(i=1,2, \ldots, m ; j=1,2, \ldots, n) \\
& D_{i}=\frac{D_{i}^{-}}{D_{i}^{-}+D_{i}^{+}} \quad ; 0 \leq D_{i} \leq 1 ; \quad(\mathrm{i}=1,2, \ldots, \mathrm{m})
\end{aligned}
$$

\section{Financial performance of companies}

Performances of companies operating in electrical energy production field and transacted in Istanbul stock Exchange are evaluated according to economic data using TOPSIS. At the date this study was conducted performances of these six companies (AKENER, AKSEN, AKSUE, 
İlkuçar, M., Çifci, A. (2016). Performance evaluation of electricity generation companies traded on BIST according to the financial parameters through the application of TOPSIS method. International Journal of Social Sciences and Education Research, 2 (3), 815-824.

AYEN, ODAS, ZOREN) (See Table 1) where calculation economic data in 2015 Where calculated using economical data. Acknowledged company evaluation method was used as performance criteria is shown in Table 3) (Aytekin and Sakarya, 2013). The data used in this study were acquired from KAP (2016) and BIGPARA (2016) web pages. Twelve different criteria were used to assess the company performances. The criteria were dived to two groups according to their contribution to performance as profit and cost. Since $\mathrm{C}_{1}, \mathrm{C}_{3}, \mathrm{C}_{4}, \mathrm{C}_{5}, \mathrm{C}_{6}, \mathrm{C}_{7}, \mathrm{C}_{8}, \mathrm{C}_{10}$ criteria values are designated as benefit, they contribute positively, and $\mathrm{C}_{2}, \mathrm{C}_{9}, \mathrm{C}_{11}, \mathrm{C}_{12}$ criteria values are designated as cost, they affect performance negatively. Current rate $\left(\mathrm{C}_{9}\right)$ criterion value was designated as absolute distinct from the average of sector (Table 4). Distinct value is to be calculated as absolute value as it gains distance from average, positive contribution $\mathrm{C}_{9}$ is to decrease as a result $\mathrm{C}_{9}$ value is to be calculated as cost.

Table 3. Description of criteria

\begin{tabular}{|c|l|l|}
\hline Denote & \multicolumn{1}{|c|}{ Criterion } & \multicolumn{1}{|c|}{ Contribution } \\
\hline $\mathbf{C}_{\mathbf{1}}$ & Price-Earnings Ratio: An In-Depth Guide & Benefit \\
\hline $\mathbf{C}_{\mathbf{2}}$ & Pprice-To-Book Ratio: Market Value & Cost \\
\hline $\mathbf{C}_{\mathbf{3}}$ & Net Profit / Total Assets ratio: Return On Assets & Benefit \\
\hline $\mathbf{C}_{\mathbf{4}}$ & Net Profit / equity ratio : Return On Equity & Benefit \\
\hline $\mathbf{C}_{\mathbf{5}}$ & Market Value / Net Sales Ratio & Benefit \\
\hline $\mathbf{C}_{\mathbf{6}}$ & Market Value / Operating Profit Ratio & Benefit \\
\hline $\mathbf{C}_{\mathbf{7}}$ & Net Profit/Net Sales Ratio & Benefit \\
\hline $\mathbf{C}_{\mathbf{8}}$ & Operating Profit / Net Sales Ratio & Benefit \\
\hline $\mathbf{C}_{\mathbf{9}}$ & Current Rate (absolute distinct from the average of sector) & Cost \\
\hline $\mathbf{C}_{\mathbf{1 0}}$ & Operating Profit / Short Term Debt Ratio & Benefit \\
\hline $\mathbf{C}_{\mathbf{1 1}}$ & Short Term Debt / Total Assets Ratio & Cost \\
\hline $\mathbf{C}_{\mathbf{1 2}}$ & Short Term Debt / Total Debt Ratio & Cost \\
\hline
\end{tabular}

Data used in this study is placed in Table 5 as illustrated. Companies (alternatives- $\mathrm{A}_{\mathrm{i}}$ ) are indicated with $i$ and criteria as $j$. Mathematically it can be stated as in Equation 1. The flow chart in Figure 2 is to be initiated, alternatives, criteria and coefficients of the alternatives are assigned and then placed as illustrated in Table 4 and TOPSIS calculation process is initiated. Sum of criteria value squares are squared $\left(\mathrm{Y}_{\mathrm{i}}\right)$ (Equation 2). It shows that last two rows in Table 4. As in Equation 3 every element of the matrix are normalized. After this process a measure is acquired as $[0,1]$ unchanging the ratio of data(Table 6$)$.

Table 4. Performance criteria values of Energy Production Companies transacted in BIST

\begin{tabular}{rcccccc}
\cline { 2 - 6 } & \multicolumn{7}{c}{ Alternative } \\
\cline { 2 - 7 } $\mathrm{C}_{9}$ criteria value & $\mathrm{A}_{1}$ & $\mathrm{~A}_{2}$ & $\mathrm{~A}_{3}$ & $\mathrm{~A}_{4}$ & $\mathrm{~A}_{5}$ & $\mathrm{~A}_{6}$ \\
\cline { 2 - 7 } & 0,5 & 0,58 & 4,42 & 0,82 & 0,80 & 0,33 \\
\cline { 2 - 6 } $\mathrm{C}_{9-\mathrm{n}}=\left|\mathrm{C}_{9-\text { mean }}-\mathrm{C}_{9}\right|$ & $\mathrm{C}_{9 \text { mean }}=7,45$ & ; which is arithmetic mean of $\mathrm{C}_{9}$ \\
\cline { 2 - 7 } & 0,742 & 0,662 & 3,178 & 0,422 & 0,422 & 0,912 \\
\cline { 2 - 6 }
\end{tabular}


İlkuçar, M., Çifci, A. (2016). Performance evaluation of electricity generation companies traded on BIST according to the financial parameters through the application of TOPSIS method. International Journal of Social Sciences and Education Research, 2 (3), 815-824.

Table 5. Performance criteria values of Energy Production Companies transacted in BIST

\begin{tabular}{|c|c|c|c|c|c|c|c|c|c|c|c|c|}
\hline & $\mathrm{C}_{1}$ & $\mathrm{C}_{2}$ & $\mathrm{C}_{3}$ & $\mathrm{C}_{4}$ & $C_{5}$ & $\mathrm{C}_{6}$ & $\mathrm{C}_{7}$ & $\mathrm{C}_{8}$ & $C_{9, n}$ & $\mathrm{C}_{10}$ & $\mathrm{C}_{11}$ & $\mathrm{C}_{12}$ \\
\hline $\mathbf{A}_{1}$ & 0 & 1,52 & $-0,1$ & $-0,63$ & 0,69 & $-14,15$ & $-0,29$ & $-0,05$ & 0,742 & \begin{tabular}{|l|}
$-0,09$ \\
\end{tabular} & 0,19 & 0,22 \\
\hline $\mathbf{A}_{2}$ & 41,32 & 1,16 & 0,01 & 0,04 & 0,84 & 7,36 & 0,02 & 0,11 & 0,662 & 0,24 & 0,26 & 0,38 \\
\hline $\mathbf{A}_{3}$ & 0 & 1,88 & $-0,03$ & $-0,03$ & 39,97 & $-369,24$ & $-0,72$ & $-0,11$ & 3,178 & $-0,2$ & 0,02 & 0,09 \\
\hline $\mathbf{A}_{4}$ & 12,75 & 1,42 & 0,02 & 0,11 & 1,49 & 7,19 & 0,12 & 0,21 & 0,422 & 0,15 & 0,22 & 0,27 \\
\hline $\mathbf{A}_{5}$ & 14,57 & 1,25 & 0,04 & 0,09 & 0,6 & 7,61 & 0,04 & 0,08 & 0,422 & 0,28 & 0,25 & 0,46 \\
\hline$A_{6}$ & 0 & 1,88 & $-0,05$ & $-0,42$ & 1,23 & 21,5 & $-0,28$ & 0,06 & 0,912 & 0,02 & 0,39 & 0,44 \\
\hline $\operatorname{Sum}\left(\mathrm{Y}_{\mathrm{i}}\right)$ & \begin{tabular}{|l|}
2072,287 \\
\end{tabular} & 14,304 & 0,016 & 0,596 & 1602,876 & 137164,428 & 0,697 & 0,081 & 12,294 & 0,207 & 0,367 & 0,679 \\
\hline Sqrt(Yi) & 45,522 & 3,782 & 0,124 & 0,772 & 40,036 & 370,357 & 0,835 & 0,284 & 3,506 & 0,455 & 0,606 & 0,824 \\
\hline
\end{tabular}

Table 6. Normalized table

\begin{tabular}{|l|r|r|r|r|r|r|r|r|r|r|r|c|}
\cline { 2 - 13 } \multicolumn{1}{c|}{} & \multicolumn{1}{c|}{$\mathbf{C}_{\mathbf{1}}$} & \multicolumn{1}{c|}{$\mathbf{C}_{\mathbf{2}}$} & \multicolumn{1}{c|}{$\mathbf{C}_{\mathbf{3}}$} & \multicolumn{1}{c|}{$\mathbf{C}_{\mathbf{4}}$} & \multicolumn{1}{c}{$\mathbf{C}_{\mathbf{5}}$} & \multicolumn{1}{c}{$\mathbf{C}_{\mathbf{6}}$} & \multicolumn{1}{c}{$\mathbf{C}_{\mathbf{7}}$} & \multicolumn{1}{c}{$\mathbf{C}_{\mathbf{8}}$} & $\mathbf{C}_{\mathbf{9}}$ & $\mathbf{C}_{\mathbf{1 0}}$ & $\mathbf{C}_{\mathbf{1 1}}$ & $\mathbf{C}_{\mathbf{1 2}}$ \\
\hline $\mathbf{A}_{\mathbf{1}}$ & 0 & 0,402 & $-0,806$ & $-0,816$ & 0,017 & $-0,038$ & $-0,347$ & $-0,176$ & 0,212 & $-0,198$ & 0,314 & 0,267 \\
\hline $\mathbf{A}_{\mathbf{2}}$ & 0,905 & 0,307 & 0,081 & 0,052 & 0,021 & 0,02 & 0,024 & 0,387 & 0,189 & 0,527 & 0,429 & 0,461 \\
\hline $\mathbf{A}_{\mathbf{3}}$ & 0 & 0,497 & $-0,242$ & $-0,039$ & 0,998 & $-0,997$ & $-0,862$ & $-0,387$ & 0,906 & $-0,44$ & 0,033 & 0,109 \\
\hline $\mathbf{A}_{\mathbf{4}}$ & 0,28 & 0,375 & 0,161 & 0,142 & 0,037 & 0,019 & 0,144 & 0,739 & 0,120 & 0,33 & 0,363 & 0,328 \\
\hline $\mathbf{A}_{\mathbf{5}}$ & 0,32 & 0,331 & 0,323 & 0,117 & 0,015 & 0,021 & 0,048 & 0,282 & 0,126 & 0,615 & 0,413 & 0,558 \\
\hline $\mathbf{A}_{\mathbf{6}}$ & 0 & 0,497 & $-0,403$ & $-0,544$ & 0,031 & 0,058 & $-0,335$ & 0,211 & 0,260 & 0,044 & 0,644 & 0,534 \\
\hline
\end{tabular}

According to the opinion of an expert, criteria are assigned with $\mathrm{w}_{\mathrm{i}}$ weight values. Sum of criteria weight values must be equal to $1\left(\left(\sum_{j=1}^{n} w_{j}=1\right)\right.$. In this study, all criteria are assigned with equal weight values. Weight values of every criterion are designated as $w_{i}=1 /$ number_of_criteria (1/12). By multiplying criterion weight values with normalized values, weighted vector (Equation 4) is acquired (Table 7).

Table 7. Vector table which is weighted according to $\mathrm{w}_{\mathrm{j}}$ weight value

\begin{tabular}{|c|c|c|c|c|c|c|c|c|c|c|c|c|}
\hline & $\mathrm{C}_{1}$ & $\mathrm{C}_{2}$ & $\mathrm{C}_{3}$ & $\mathrm{C}_{4}$ & $\mathrm{C}_{5}$ & $\mathrm{C}_{6}$ & $\mathrm{C}_{7}$ & $\mathrm{C}_{8}$ & $\mathrm{C}_{9}$ & $C_{10}$ & $\mathrm{C}_{11}$ & $C_{12}$ \\
\hline $\mathbf{A}_{1}$ & 0 & 0,033 & $-0,067$ & $-0,068$ & 0,001 & $-0,003$ & $-0,029$ & $-0,015$ & 0,018 & $-0,016$ & 0,026 & 0,022 \\
\hline 1 & 775 & 0,025 & 0,007 & 0,004 & 0,002 & 0,002 & 0,002 & 0,032 & $0, \mathrm{C}$ & 0,0 &, 036 & 0,038 \\
\hline$\overline{\mathbf{A}_{3}}$ & 0 & 0,041 & $-0,02$ & $-0,003$ & 0,083 & $-0,083$ & $-0,072$ & $-0,032$ & 0,075 & $-0,037$ & 0,003 & 0,009 \\
\hline$\overline{\mathbf{A}_{4}}$ & 023 & 0,031 & 0,013 & 0,012 & 0,003 & 0,002 & 0,012 & 0,061 & 0,010 & 0,027 & 0,03 & 0,027 \\
\hline $\mathbf{A}_{5}$ & 0,027 & 0,027 & 0,027 & 0,01 & 0,001 & 0,002 & 0,004 & 0,023 & 0,010 & 0,051 & 0,034 & 0,046 \\
\hline $\mathbf{A}_{6}$ & 0 & 0,041 & $-0,033$ & $-0,045$ & 0,003 & 0,005 & $-0,028$ & 0,018 & 0,022 & 0,004 & 0,053 & 0,044 \\
\hline
\end{tabular}

Table 8. Positive and negative ideal values of criteria according to benefit/cost features

\begin{tabular}{|c|r|c|c|c|c|c|c|c|c|c|c|c|}
\cline { 2 - 13 } \multicolumn{1}{c|}{} & $\mathbf{C}_{\mathbf{1}}$ & $\mathbf{C}_{\mathbf{2}}$ & $\mathbf{C}_{\mathbf{3}}$ & $\mathbf{C}_{\mathbf{4}}$ & $\mathbf{C}_{\mathbf{5}}$ & $\mathbf{C}_{\mathbf{6}}$ & $\mathbf{C}_{\mathbf{7}}$ & $\mathbf{C}_{\mathbf{8}}$ & $\mathbf{C}_{\mathbf{9}}$ & $\mathbf{C}_{\mathbf{1 0}}$ & $\mathbf{C}_{\mathbf{1 1}}$ & $\mathbf{C}_{\mathbf{1 2}}$ \\
\hline $\mathbf{A}_{\mathbf{i}}^{+}$ & 0,075 & 0,041 & 0,027 & 0,012 & 0,083 & 0,005 & 0,012 & 0,061 & 0,001 & $-0,037$ & 0,003 & 0,009 \\
\hline $\mathbf{A}_{\mathbf{i}}^{-}$ & 0 & 0,025 & $-0,067$ & $-0,068$ & 0,001 & $-0,083$ & $-0,072$ & $-0,032$ & 0,075 & 0,051 & 0,053 & 0,046 \\
\hline
\end{tabular}

In the next stage, ideal positive $\left(\mathrm{A}_{\mathrm{i}}^{+}\right)$and ideal negative $\left(\mathrm{A}_{\mathrm{i}}^{+}\right)$values are calculated in respect of benefit and cost of criteria to solution. $\mathrm{C}_{1}-\mathrm{C}_{8}$ criteria are benefit, $\mathrm{C}_{9}-\mathrm{C}_{12}$ criteria are cost and according to Equation 5, for ideal positive, benefit criteria must be maximum and cost criteria minimum, for ideal negative according to Equation 6 , benefit criteria must be minimum whereas cost criteria must be maximum. As an example; $\mathrm{C}_{2}$ criterion in Table 6 is profit and to find the ideal positive, highest value of $\mathrm{C}_{2}$ column 0.041 is used. Similarly, to find the ideal negative for $\mathrm{C}_{2}$ lowest value of the column, 0.025 is used. By doing this, positive and negative ideal values of every criterion are acquired (Table 8 ). 
İlkuçar, M., Çifci, A. (2016). Performance evaluation of electricity generation companies traded on BIST according to the financial parameters through the application of TOPSIS method. International Journal of Social Sciences and Education Research, 2 (3), 815-824.

Table 9. The weight of criteria

\begin{tabular}{ccccccccccccc}
\hline $\begin{array}{c}\text { Crite- } \\
\text { ria }\end{array}$ & $\mathbf{C}_{\mathbf{1}}$ & \multicolumn{1}{c}{$\mathbf{C}_{\mathbf{2}}$} & \multicolumn{1}{c}{$\mathbf{C}_{\mathbf{3}}$} & $\mathbf{C}_{\mathbf{4}}$ & $\mathbf{C}_{\mathbf{5}}$ & \multicolumn{1}{c}{$\mathbf{C}_{\mathbf{6}}$} & $\mathbf{C}_{\mathbf{7}}$ & $\mathbf{C}_{\mathbf{8}}$ & \multicolumn{1}{c}{$\mathbf{C}_{\mathbf{9}}$} & $\mathbf{C}_{\mathbf{1 0}}$ & $\mathbf{C}_{\mathbf{1 1}}$ & $\mathbf{C}_{\mathbf{1 2}}$ \\
\hline $\mathbf{W}_{\mathbf{1}}$ & $1 / 12$ & $1 / 12$ & $1 / 12$ & $1 / 12$ & $1 / 12$ & $1 / 12$ & $1 / 12$ & $1 / 12$ & $1 / 12$ & $1 / 12$ & $1 / 12$ & $1 / 12$ \\
$\mathbf{W}_{\mathbf{2}}$ & 0,1 & 0,1 & 0,1 & 0,075 & 0,075 & 0,075 & 0,075 & 0,1 & 0,075 & 0,075 & 0,075 & 0,075 \\
\hline
\end{tabular}

Table 10. Distance value of alternative from ideal positive and negative

\begin{tabular}{cccccccc}
\hline & & & $\mathbf{W}_{\mathbf{1}}$ & & \multicolumn{3}{c}{$\mathbf{W}_{\mathbf{2}}$} \\
\hline Alternative & Companies & $\boldsymbol{D}_{\boldsymbol{i}}^{+}$ & $\boldsymbol{D}_{\boldsymbol{i}}^{-}$ & Performance & $\boldsymbol{D}_{\boldsymbol{i}}^{+}$ & $\boldsymbol{D}_{\boldsymbol{i}}^{-}$ & Performance \\
\hline $\mathbf{A}_{\mathbf{1}}$ & AKENR & 0,201 & 0,117 & 0,368 & 0,215 & 0,106 & 0,333 \\
$\mathbf{A}_{\mathbf{2}}$ & AKSEN & 0,100 & 0,209 & 0,676 & 0,095 & 0,214 & 0,693 \\
$\mathbf{A}_{\mathbf{3}}$ & AKSUE & 0,209 & 0,130 & 0,383 & 0,216 & 0,124 & 0,365 \\
$\mathbf{A}_{\mathbf{4}}$ & AYEN & 0,105 & 0,213 & 0,670 & 0,104 & 0,218 & 0,677 \\
$\mathbf{A}_{\mathbf{5}}$ & ODAS & 0,114 & 0,210 & 0,648 & 0,115 & 0,210 & 0,646 \\
$\mathbf{A}_{\mathbf{6}}$ & ZOREN & 0,169 & 0,136 & 0,446 & 0,176 & 0,131 & 0,427 \\
\hline
\end{tabular}

Table 11. Performance order of alternatives different weight according to proportional values of positive and negative ideal

\begin{tabular}{clllll}
\hline \multicolumn{2}{c}{$\mathbf{W}_{\mathbf{1}}$} & & \multicolumn{2}{c}{$\mathbf{W}_{\mathbf{2}}$} \\
\hline Order \# & Alternative & Performance & Order \# & Alternative & Performance \\
\hline 1 & AKSEN & 0,676 & 1 & AKSEN & 0,693 \\
2 & AYEN & 0,670 & 2 & AYEN & 0,677 \\
3 & ODAS & 0,648 & 3 & ODAS & 0,646 \\
4 & ZOREN & 0,446 & 4 & ZOREN & 0,427 \\
5 & AKSUE & 0,383 & 5 & AKSUE & 0,365 \\
6 & AKENR & 0,368 & 6 & AKENR & 0,330 \\
\hline
\end{tabular}

In weighted table (Table 7) relative deviation of every criterion to ideal positive and negative (Table 8) are calculated using Euclidian distance formula (Equation 7 and 8).

$\boldsymbol{D}_{\boldsymbol{i}}^{+}$is the deviation from positive ideal and, $\boldsymbol{D}_{\boldsymbol{i}}^{-}$is the deviation from negative ideal solution. In Table 8, distance calculations of ideal positive and negative solutions are done. Later in the study, relative distance from ideal positive and negative solution is calculated (Equation 9) and performance values are acquired. Performance is calculated different weight values (Table 9). Two different weight's performance values of Table 10 is illustrated in descending order in Table 11. According to this order, company with the best performance is AKSEN, worst is AKENR. AYEN close to AKSEN, and AKSUE close to AKENR.

\section{Conclusions and recommendations}

Companies engaged in electricity energy generation, traded in the Borsa İstanbul, are evaluated according to the acknowledged evaluation criteria. TOPSIS performance evaluation method is used since this is a multi-criteria decision problem. Six companies are listed in descending order according to 2015 economic data criteria and company performance. As a result, company with the best performance was AYEN, and the company with the worst performance was AKENER. 
İlkuçar, M., Çifci, A. (2016). Performance evaluation of electricity generation companies traded on BIST according to the financial parameters through the application of TOPSIS method. International Journal of Social Sciences and Education Research, 2 (3), 815-824.

In this study, a software which can create solutions according to TOPSIS method was developed using C\#.Net. Problem was solved through the use of the developed program. Software has the flexibility to be used in similar studies.

\section{References}

Aktaş R., Doğanay M.M., Gökmen Y., Gazibey Y., Türen U., (2015). Sayısal Karar Verme Yöntemleri. Beta Basın Yayın Dă̆ıtım, İstanbul, Ocak 2015.

Aytekin S., Sakarya Ş. (2013). BIST’de İşlem Gören Gıda İşletmelerinin TOPSIS Yöntemi İle Finansal Performanslarının Değerlendirilmesi. Yönetim ve Ekonomi Araştırmaları Dergisi - Sayı:21 (2013) Doi: http://dx.doi.org/10.11611/JMER191

BIGPARA (2016). http://www.bigpara.com/analiz/mali-tablolar/ (23/03/2016).

BIST (2016). http://www.borsaistanbul.com/ (20/03/2016).

Bülbül, S., Köse A. (2009). Türk Gıda Şirketlerinin Finansal Performansının Çok Amaçlı Karar Verme Yöntemleriyle Değerlendirilmesi. Atatürk Ü. İ̈BF Dergisi, 10. Ekonometri ve İstatistik Sempozyumu Özel Saylsı, 71-97.

Dumanoğlu, S., N. Ergül (2010), İMKB'de İşlem Gören Teknoloji Şirketlerinin Mali Performans Ölçümü. Muhasebe ve Finansman Dergisi, 48, 101-111.

Ertuğrul, İ., Karakaşoğlu N. (2009). Performance evaluation of Turkish cement firms with fuzzy analytic hierarchy process and TOPSIS methods. Expert Syst. Appl., 36 (1), pp. 702-715

Feng, C. M., R. T. Wang (2000), Performance Evaluation for Airlines Including the Consideration of Financial Ratios. Journal of Air Transport Management, 6, 133-142.

Halkos, G.E., Tzeremes N.G. (2012). Industry performance evaluation with the use of financial ratios: an application of bootstrapped DEA. Expert Syst Appl, 39 (5), 5872-5880.

Hwang, C.L., \& Yoon, K. (1981). Multiple attribute decision making: Methods and applications. Springer. http://dx.doi.org/10.1007/978-3-642-48318-9.

KAP (2016). https://www.kap.gov.tr/ (20/03/2016).

Mandic, K., Delibasic, B., Knezevic, S., Benkovic, S. (2014). Analysis of the financial parameters of Serbian banks through the application of the fuzzy AHP and TOPSIS methods. Economic Modelling, 43, 30-37.

Meydan, C., Yıldırım, B. F., Senger, Ö. (2016). BIST’te İşlem Gören Gıda İşletmelerinin Finansal Performanslarının Gri İlişkisel Analiz Yöntemi Kullanılarak Değerlendirilmesi. Muhasebe ve Finansman Dergisi, 147-167.

OIB (2004). http://www.oib.gov.tr/program/2004_program/ 2004_electricity_strategy_paper.htm $(20 / 02 / 2016)$

Özçelik H., Kandemir B. (2015). BIST'de İşlem Gören Turizm İşletmelerinin TOPSIS Yöntemi ile Finansal Performanslarının Değerlendirilmesi. Balkesir University The Journal of Social Sciences Institute, 18 (33), 97-114.

Özdağoğlu A.,(2013).The Effects of Different Normalization Methods to Decision Making Process in TOPSIS. Ege Academic Review, 13 (2), 245-257.

TEIAS (2015). Electricity Generation \& Transmission Statistics of Turkey, 2015, 
İlkuçar, M., Çifci, A. (2016). Performance evaluation of electricity generation companies traded on BIST according to the financial parameters through the application of TOPSIS method. International Journal of Social Sciences and Education Research, 2 (3), 815-824.

TEIAS (2016). Turkish Electricity Transmission Corporation (TEIAS). Short history of electrical energy development in Turkey and some statistical figures. Available from: http://www.teias.gov.tr/ [in Turkish]

Uygurtürk H., Korkmaz T., (2012). Finansal performansın TOPSIS çok kriterli karar verme yöntemi ile belirlenmesi: Ana metal sanayi işletmeleri üzerine bir uygulama. Eskişehir Osmangazi Univ IIBF J. 7:95-115.

Yu X.,, Guo S., Guo J., Huang X. (2011). Rank B2C e-commerce websites in e-alliance based on AHP and Fuzzy TOPSIS. Expert Systems with Application 38 (2011), 3550-3557.

Yurdakul, M. ve Y. T. İç (2003), Türk Otomotiv Firmalarının Performans Ölçümü ve Analizine Yönelik TOPSIS Yöntemini Kullanan Bir Örnek Çalışma. Gazi Üni. Müh. Mim. Fak. Dergisi, 18(1), 1-18. 